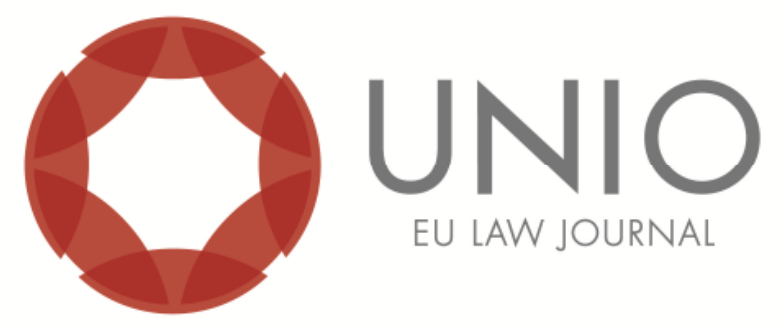

\title{
The Theories of Interconstitutionality and Transconstitutionalism. Preliminary Insights from a Jus-cultural Perspective (With a view to Transnational Social Justice)
}

\author{
Luís A. Malheiro Meneses do Vale*
}

ABSTRACT: In the following pages, some light will hopefully be shed into the recent proposals of interconstitutionality and transconstitutionalism - deemed bighly influential among Portuguese and Spanish-speaking countries - considering them against the backdrop defined by the more general disquisitions recently devoted to interculturality and transculturality in their quality of practical responses to the globalization and social differentiation phenomena. Acknowledging the fact that, even inside the juridical linguistic game and within the juristic community of interpreters, the new narratives interwoven through the above mentioned concepts are becoming more and more intricate - v.g., including epistemic and normative, as well as subjective and objective perspectives, giving birth to new elaborate semantic networks and covering an ever growing territory - it is important to admonish, at the outset, that, in this stance, we cannot but provide a preliminary and provisory map of the vast continent thereby comprised. As a consequence, the present text will limit itself to the signalling of some landmarks and the rough drawing of the basic lineaments for further (and certainly wiser and more competent) cartographic and exploratory endeavours.

KEYWORDS: interconstitutionality - interculturality - transconstitutionalism transculturality.

* Assistant Professor at the Faculty of Law of University of Coimbra. 


\section{Social Constitutional Law, Institutions and Culture}

1. The great challenges facing law, legal studies and lawyers/jurists in the first decades of this XXI century do not seem to grant us the serenity of vita contemplativa in academic marble towers; they rather demand a practical and normative compromise with a more righteous, correct, just and better world.

Over the past few years, my own modest commitment to the irrecusable Kampf um Recht und Rechtwissensschaft of our times, led me to delve into the juridical institutionalization of the normative project of social justice, as assumed by law and enacted in republican terms (that surpass a mere judicial - adjudicatory - enforcement), attempting to assess it from a jusconstitutional perspective, particularly focused on the specific societal sphere structured around healthcare.

Drawing on inter- and trans-disciplinary achievements - spurred, among other things, by the recent and widely acclaimed cultural and institutional turns - I have been striving to outline the essential features of what could be regarded as a new common ${ }^{1}$ public social law with constitutional aspirations, anchored in social rights (and their institutional assumptions and projections), increasingly formed via

\footnotetext{
-This article was submitted and accepted to be presented at the Training School on International Law Between Pluralism and Constitutionalism, organized by CEDU (Centre of Studies in European Union Law, University of Minho) within COST Action 1003, in 2012, under the theme International Law Between Fragmentation and Constitutionalisation. The text still bears the marks of those origins and primeval intentions. Despite the natural evolutions and changes that my own thought has suffered in the meantime, the preference was to keep the article largely untouched, with exceptions made to a set of graphics and schemes that it originally contained (as anexes), but were hereby suppressed, unfitted as they seemed to this space.

For clarifications purposes, it could be added that the original paper was born at the crossroads of two broader research projects. The first one concerns my $\mathrm{PhD}$ investigations on the juridical realization of social justice in healthcare systems, and the second one consists of a comparative and historical analysys of constitutional experiences (Icelandic, Turkish, Israeli, Napolitan), located somehow at the margins of the mainstream constitutional thought, a study which was envisaged as a means to test and filter theoretical postulates cogitated and propugnated, over the past few years, on matters of inter- and trans- culturality and constitutionality . Some aspects of these perquiritions naturally overlap, because $\mathrm{my} \mathrm{PhD}$ studies tend to nurture all other reflections and reap the fruits resulting therefrom. Further and detailed developments on the subject hereby explored will thus hopefully be found in my final dissertation. Nevertheless, they can already be glimpsed in articles published in the meantime, especially in "Breves apontamentos sobre o Direito Constitucional da República da Turquia. Contributo para uma recompreensão inter- e trans-cultural da jusconstitucionalidade contemporânea? (1. " Parte)", in Boletim da Faculdade de Direito da Universidade de Coimbra, Vol. XXXVIII, Tomo II, pp. 727-787; "Breves apontamentos sobre o Direito Constitucional da República da Turquia. Contributo para uma recompreensão inter- e

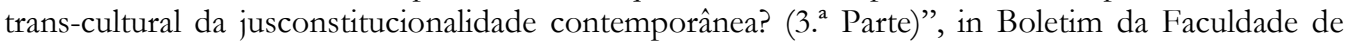
Direito da Universidade de Coimbra, Vol. LXXXIX, Tomo II, 2013 , pp. 721-748. I also had the oportunity to return to these issues in three recent presentations: «Inter- e transconstitucionalidade como expressão e factor de inter- e transculturalidade: subsídios para uma reconsideração da teoria e do direito constitucionais?» (at the IV Colóquio Macrofilosófico e I Colóquio sobre Interconstitucionalidade, organized by CEDU - University of Minho, the University of Barcelona and the University Autónoma de Barcelona) and «Inter- e transconstitucionalidade como expressão e factor de inter- e transculturalidade: concurso para um projecto jurídico-políticamente transformador?» (at the Workshop "Interconstitucionalidade: teoria e hemenêutica", held at CEDU, University of Minho), and «Proto-direitos sociais e controlo jurídico-político da constitucionalidade na República Napolitana (1799). Reflexões sobre a sancionabilidade do direito social, a partir do projecto constitucional de Francesco Mario PAGANO» (1. ${ }^{\circ}$ Encontro de Doutorandos do Instituto Jurídico, at the Faculty of Law of the University of Coimbra).

1 Mireille Delmas-Marty, Pour un droit commun, Seuil, Paris, 1994; IDEM, Trois défis pour un droit mondial, Seuil, Paris, 1998; in Portugal, v. Eduardo Vera-Cruz PINTO, História do direito comum da humanidade: ius commune bumanitatis ou lex mundi?, Volume I., Tomo I., AAFDL, Lisboa, 2003 and Volume I, Tomo II, AAFDL, Lisboa, 2006.
} 
complex processes of intercultural communication, but also shaped (eventually) by transcultural (shared) grounds, reclaiming therefore an urgent reconsideration of the Cultural Theories of Law $^{2}$.

For the current purpose, some of the main problematical knots formed by the themes addressed in my research - e.g. social justice, republicanism, constitutionality, etc. - can be unfolded and primarily displayed along three lines of research, continuously challenged by globalization, whose shock waves seriously complicate the discharging of the nuclear reflective tasks incumbent upon us: a) first of all, the re-foundation and theorization of social juridicity, as the juridical precipitation of social justice - whilst accounting for the diversified means of its instantiation (namely through organizational, procedural and functional juridical arrangements, conflict laws and reflexive regulation) - and ultimately aiming for a clarification of sociality (as an object, content, and mission of law, more than simply its condition and ground); b) secondly, the determination of public law's specificity, distilling the particular meaning and idea of juridical publicness ${ }^{3}$ from the vast array of traditional publicization criteria of law, through an exercise of philosophical and historical reconstitution of its foundations ${ }^{4}$; c) thirdly, the reconstruction of constitutional law as a relatively autonomous field inside the juridical system - due to its particular meaning and rationality, history, foundations, contents and functions ${ }^{5}$ - and the decantation of the (hypothetical...) new social public law constitutionality by means of scrupulous distinctions between

2 V. for example, Berhnard LOSCH, Kulturfaktor Recht: Grundwerte - Leitbilder - Normen. Eine Einführung, UTB, Böhlau Verlag, Köln, 2006; Roger COTTERRELL, Law, Culture and Society: Legal Ideias in the Mirror of Social Theory, Ashgate, Burlington, 2006; David NELKEN, "Using the concept of legal culture", in Australian Journal of Legal Philosophy, 2004; Robin WEST, "Literature, Culture and Law", in Georgetown Law: The Scholarly Commons, 2008; Lawrence ROSEN, Law as Culture. An Invitation, Princeton University Press, 2006; Wolfgang FIKENTSCHER, Law and Anthropology: Outlines, Issues, Suggestions, Bayerische Akademie der Wissenschaften - Abhandlungen, München, Verlag C.H. Beck in Kommission, 2008; Norbert ROULAND, Nos Confins do Direito, Martins Fontes, São Paulo, 2003; Paul KAHN, "Freedom, Autonomy and the Cultural Study of Law", in Yale Journal of Law \& the Humanities, 13, 2001, pp. 141-171; Naomi MEZEY, "Law as Culture" in Yale Journal of Law \& the Humanities, 13, 2001, pp. 35-67; Peter HÄBERLE, Verfassungslehre als Kulturwissenschaft. Schriften zum offentlichen Recht (spanish translation: Teoria de la Constitución como ciência de la cultura, Tecnos, Madrid, 2000); IDEM, "Der Sinn von Verfassungen in kulturwissenschaftlicher Sicht”, in Archiv des öffentlichen Rechts, 131, 2006, pp. 621 and ff.; IDEM, "Verfassung als Kultur", in Jabrbuch des öffentlichen Rechts der Gegenwart. Neue Folge, 2001, V. 49, pp. 125-143; Pablo Lucas VERDÚ, "Ultima lección académica del profesor Pablo Lucas Verdu con motivo de su jubilación anticipada el 20 de mayo de 1988", in Revista de Derecho Político, núm. 27-28, 1988, pp. 9-22; IDEM, Teoría de la Constitución como Ciencia Cultural, 2. ${ }^{\text {a }}$ edición, corregida y aumentada, Dykinson, Madrid, 1998; Jack BALKIN, Cultural Software: A Theory of Ideology, Yale University Press, New Haven \& London, 1998; Mark van HOECKE, Law as Communication, Hart Publishing, Oxford, 2002; Miguel REALE, Filosofia do Direito, 19. ${ }^{a}$ edição 3. ${ }^{a}$ tiragem, Saraiva, São Paulo, 2002.

${ }^{3}$ See, for all: Armin von BOGDANDY/ Philipp DANN/ Matthias GOLDMANN, "Developing the Publicness of Public International Law: Towards a Legal Framework for Global Governance Activities", in German Law Journal, Vol. 9, 2008, pp. 1375-1400.

4 R.C. Van CAENEGEN, Uma Introdução Histórica ao Direito Constitucional Ocidental, Fundação Calouste Gulbenkian, Lisboa, 2007; Maurizio FIORAVANTI, Constitución. De la Antigüedad a nuestros dias, Editorial Trotta, Madrid, 2007; Olivier BEAUD, "L'Histoire du Concept de Constitution en France. De la Constitution Politique à la Constitution comme Statut Juridique de L'État", in Jus Politicum. Revue de droit politique, n. ${ }^{\circ}$ 2, 2010, pp. 31-59; Gerhard STOURZH, "Constitution: Changing Meanings of the Term from the Early 17th to the late 18th Century, in T. H. BALL/ J. G. A. POCOCK (Eds.), Conceptual Change and the Constitution, University Press of Kansas, Lawrence, 1988, pp. 35 and ff.; Rogério SOARES, "O Conceito Ocidental de Constituição", in Revista de Legislação e de Jurisprudência, n. ${ }^{\circ}$ s 3743 e 3744.

5 Presently in need of an urgent critical reconstruction. 
constitution, constitutionalism (as a political movement), constitutionalization (taken as a process) and constitutionality - with the latter being used to designate the constitutional normativity (understood in its quid, eidos, ousia or noetic/noematic content) ${ }^{6}$.

2. In a global setting, characterized by strong individualization, privatization and politico-juridical fragmentation, it seems unnecessary to highlight how many and how big are the obstacles and resistance encountered, each and every time one attempts to uphold a critical rehabilitation and reinvention of juridical sociality, publicity and constitutionality.

Sociality appears to have retreated, gradually receding from substantive to procedurall discursive (J. HABERMAS), and then conflict regions of law (C. JOERGES), to find its last refuge in mere reflexive juridicity (K-H. LADEUR). And yet, social rights and principles, duties and responsibilities remain constitutive grounds and regulative ideals of law, in spite of all the new juridical configurations generated by fruitful synergies between different generations of rights, the entwinement of solidarity, sustainability and subsidiarity, and the return of responsibility (individual and collective, internal and external) ${ }^{7}$.

Publicness appears somehow diluted in the all-encompassing privatized and economically functionalized global administrative law ${ }^{8}$ whose rapid dissemination tends to obliterate the central, constitutive and politically foundational role of all public law.

In regards to constitutional law, these problems assume even bigger proportions. Nevertheless, the crisis of national constitutions (torn apart by endogenous and exogenous forces), the uncertainties of constitutional theory and the obsolescence and impotency of constitutionalism ended up giving way to a new constitutional momentum, marked by the emergence of numerous trends (v.g. global, societal, multi-level, cooperative, commonwealth or neo-constitutionalisms).

Clearly, constitutionality and contitutionalness stand at the crossroads, caught in between contrasting views and contradictory movements, like pan-constitutionalist euphoria and constitutional melancholy, scepticism or even cynicism?

Without contempt for Rainer Wahls's brilliant remarks concerning the empirical social and political conditions for constitutional effectiveness ${ }^{10}$, and notwithstanding Dieter Grimm's always incisive and enlightening observations about our current constitutional reality ${ }^{11}$, constitutions still matter ${ }^{12}$, as irreplaceable media for collective self-representation and projection, as well as for intra- and

\footnotetext{
${ }^{6}$ Allow me to recall that the efforts required in order to fulfil the demands of the abovementioned public and constitutional law project of social justice within the different societal arenas (J. ELSTER), contexts (R. FORST), campus (P. BOURDIEU), spaces (L. BOLTANSKI), spheres (M. WALZER) or subsystems (N. LUHMANN) can be clearly illustrated with the case of healthcare which has generated its own geographically global but functionally partial societal constitution (G. TEUBNER).

${ }^{7}$ Just think of the consistent contributions from authors such as R. Arango, A. Supiot, C. M. Herrera, I. Sarlet, U. Vollkmann, M. Krennerich, E. Eischenhoffer, F. Michellman, W. Forbath, R. West, K. Young (to name but a few).

${ }^{8}$ Benedict KINGSBURY/ Nico KRISCH/Richard B. STEWART, "The Emergence of Global Administrative Law", Law and Contemporary Problems, 68, 2005.

${ }^{9}$ Caused by Entkonstitutionalisierung (HÖFFE) or Deconstituzionalizzarione (DUSO) processes.

10 "Konstitutionalisierung - Leitbegriff oder Allerweltsbegriff?" in Carl-Eugen/ Martin Ibler/ Dieter Lorenz (Hrsg.), Der Wandel des Staates vor den Herausforderungen der Gegenwart, Festschrift für Winfried Brohm zum 70. Geburtstag, Beck, München, 2002, pp. 191 - 207.

${ }^{11}$ See, for example, Dieter GRIMM, "The Constitution in the Process of Denationalization", in Constellations, Volume 12, No 4, 2005, pp. 447-463.

12 Mark TUSHNETT, Why the Constitution Matters?, Yale University Press, 2010.
} 
inter- societal relationships ${ }^{13}$. Constitutionality embodies a particular meaning ${ }^{14}$, rationality ${ }^{15}$ and perspective or mindset ${ }^{16}$, with normative ${ }^{17}$ material $^{18}$ contents (scilicet, goods, principles, rights and norms) $)^{19}$, which is practically revealed and continuously performed ${ }^{20}$ - although only gradually or incrementally ${ }^{21}$ - not only under, but also besides, behind or beyond the traditional formal constitutional documents; it is as though it was partially or entirely detached from the usual constitutionalist processes and constituent powers, in a strange morphogenesis ${ }^{22}$ that is growing in complexity from day to day. The main problem, in this case, concerns the relation between politics and law, democracy and juridicity and the

13 Since they can design a common normative horizon, punctuated by institutions able to generate capabilities of action and interaction, according to Ulrich PREUß, "Disconnecting Constitutions from Statehood: Is global Constitutionalism a viable concept?", in Martin LOUGHLIN/Petra DOBNER, The twilight of constitutionalism?, op. cit., pp. 23-46.

${ }^{14}$ Günther TEUBNER, "A Constitutional Moment? The Logics of 'Hitting the Bottom'”, in Poul KJAER/Gunther TEUBNER/ Alberto FEBBRAJO (eds.), Financial Crisis in Constitutional Perspective: The Dark Side of Functional Differentiation, Hart, Oxford, 2011, pp. 9-51; IDEM, "Societal Constitutionalism: Alternatives to State-Centred Constitutional Theory?”, in Christian JOERGES/ Inger-Johanne SAND/ Gunther TEUBNER (eds.), Transnational Governance and Constitucionalism, Hart, Oxford, 2004, pp. 3- 28; IDEM, "Constitutionalising Polycontexturality", in Social and Legal Studies, 19, 2010, pp. 17-38.

15 Neil WALKER, "Taking Constitutionalism beyond the State", in Political Studies, Vol. 56, 2008, pp. 519-543.

${ }_{16}$ Martti KOSKENNIEMI, "Constitutionalism as Mindset: Reflections on Kantian Themes About International Law and Globalization", in Theoretical Inquiries in Law, 8, 1, 2006, pp. 9-36.

17 Thomas COTTIER/ Maya HERTIG, "The Prospects of 21st Century Constitutionalism", in Max Planck UNYB, 2003, pp. 261-328;

18 Anne PETERS, "Global Constitutionalism in a Nutshell", in: Klaus DICKE/Stephan HOBE/Karl-Ulrich MEYN/Anne PETERS/Eibe RIEDEL/Hans-Joachim SCHÜTZ/Christian TIETJE (Eds), Weltinnenrecht: Liber amicorum Jost Delbrück (Veröffentlichungen des Walther Schücking-Instituts für Internationales Recht an der Universität Kiel, Band 155), Duncker \& Humblot, Berlin, 2005; IDEM, "Compensatory Constitutionalism: The Function and Potential of Fundamental International Norms and Structures", in Leiden Journal of International Law, 19, 2006, pp. 579-610; IDEM, “Transnational Law Comprises Constitutional, Administrative, Criminal, and Quasiprivate Law”, in: Pieter BEKKER/Rudolf DOLZER/Michael WAIBEL (Eds), Making Transnational Law Work: Liber Amicorum Detlev Vagts, Cambridge University Press, Cambridge, 2010, pp. 154-173; Jan KLABBERS/ Anne PETERS/ Geir ULFSTEIN, The Constitutionalization of International Law (expanded paperback edition with new epilogue), Oxford University Press, Oxford, 2011.

19 In a thick description, occidental constitutions still withold some functional and substantive definition or predicative elements, for they are engaged with the legitimation, taming and control of state and new societal powers, conforming social and political life in the name of human dignity, pluralistic democracy, fundamental rights (including social ones), separation of powers, independendece of the judiciary power and the courts, rule of law and Rechtstaat (P. HÄBERLE).

20 «Constitutional authority is in part derived from the constitutional principles it claims to instantiate and give concrete shape to. (...) The normative presuppositions of constituionalism are translated directly into a set of basic formal, jurisdictional, procedural, and substantive legal principles that are conceived as underlying existing legal and political practices and in light of which that practice can be reconstructed and assessed». Matthias KUMM, "The Best of Times and the Worst of Times. Between Constitutional Triumphalism and Nostalgia”, in Martin LOUGHLIN/ Petra DOBNER (ed.), The twilight of constitutionalism?, Oxford University Press, Oxford/New York, 2009, pp. 201-219; IDEM, Mattias Kumm, 'The Cosmopolitan Turn in Constitutionalism: On the Relationship between Constitutionalism in and Beyond the State' in Jeffrey DUNOFF/Joel TRACHTMAN (Eds), Ruling the World? Constitutionalism, International Law and Global Governance, CUP, 2009, pp. 264 and ff.

${ }^{21}$ Thomas COTTIER/ Maya HERTIG, “The Prospects of 21 st Century Constitutionalism”, op. cit, and Neil WALKER, "Taking Constitutionalism beyond the State", op. cit.

22 Riccardo PRANDINI, "The Morphogenesis of Constitutionalism", in Martin LOUGHLIN/Petra DOBNER, The Twilight of Constitutionalism?, op. cit., pp. 309-326. 
empirical and normative dimensions of constitutionality as a specific kind of effective normative validity ${ }^{23}$.

3. Considerations of such a kind inevitably force us to dive into deeper waters, undertaking general inquiries about law itself.

As a matter of fact, in the new globalized scenario marked by axiological, epistemic, functional and geographical differentiation and pluralism, they prompt us to lucubrate on the mutually constitutive dialectic between normative validity and social problems, which lays at the heart of all living law, including the social one, thence calling out for an attentive review of its: a) rationality, conditions, foundation, content and functions; b) modus of existence (as an ought which is), normative modalities - subjective (social rights) and objective (social principles and criteria) ${ }^{24}$ , sources and dogmatic coagulations (as a system); c) and also methodology (the logoi and methods involved in its realization $)^{25}$.

At the same time, with the scope of revalorizing the alternatives to the judicial Rechtsgeninnung (not disregarding its undisputed centrality) ${ }^{26}$, they ask for a careful study of the relations among law, its individual and collective subjects (both as addressees and authors), their actions, and the social reality (structurally, intentionally and problematically envisioned), taking the multispaciality of the Weltinnenraum (P. Sloterdijk) brought about by globalization as topological reference.

Thus, in this light, engaged in a quest both for the general and specific (concrete) meaning of social justice and its practical modes of enactment, it suffices to say, at this point, that one of the major problems that we have to deal with is the need to reconcile individual and collective subjectivities (more and more volatile, hybridized and nomadic), with institutions (increasingly eroded, corrupted and liquefied), at least if we persist in restoring the profound significance of social responsibilities, general interests, public and shared spaces and common goods. But in the liquid world of polymorphic subjects which often sail adrift, this goal can be only attained - and our compromise to social justice thereby honoured appealing - primarily to fundamental human rights and social liberties (broadly considered) and emphasizing the importance of their institutional guaranties (Einrichtungsgarantien) and normative projections ${ }^{27}$. Effectively, social rights recognized within several juridical constellations or galaxies - should be approached archeoteleologically or teleonomologically, as the groundwork for a Verantwortungsrecht, which is an Aufgaberecht of values and ends - for they convey goods (juridically delineated as entitlements), whilst assigning tasks which demand positive actions of fulfilment (facilitation, promotion, realization) ${ }^{28}$; moreover, they

\footnotetext{
${ }^{23}$ Modern constitutionality is unthinkable without some form of empirical connection to the real will of people as a political constituency (and its propper procedures of formation and expression). But democracy, for its part, has also become a normative principle, grounded on normative assumptions, and thus constitutionally guaranteed. An interesting analysis of the problem is displayed in Neil WALKER, "Constitutionalism and the Incompleteness of Democracy: An Iterative Relationship", University of Edinburgh - School of Law Working Paper Series, No 2010/25, Edinburgh, 2010 .

${ }^{24}$ In this particular case.

25 This sistematization is obviously indebted to the jurisprudentialist school of juridical thought developed in the Faculty of Law of Coimbra, by Castanheira Neves and his disciples, F. Pinto Bronze and J. M. Aroso Linhares.

${ }^{26}$ Niklas LUHMANN, Das Recht der Geselsschaft, Suhrkamp Verlag, Frankfurt a.M., 1995, pp. 297 and ff.

${ }^{27}$ Social responsibilities, solidarity duties, obligations to respect, to protect and fulfil, etc.

${ }^{28}$ Something which can be adapted from the capabilities approach of M. NUSSBAUM and A. SEN, as ROBIN WEST tried to do some years ago.
} 
should also be considered in their - apparently oxymoronic - institutional intentionality, which aims to overcome the barriers between Lifeworld and System, as well as between dogmatic stabilization and critically reflexive (and dynamising) performance (of binding normative missions). It is useless (if not dangerous) to postulate holistic models of society, with reference to a clear, discernible and normatively consequent common good (Gemeingut). However, the sheer individualism at the basis of a contractual comprehension of law, exclusively reliant on commutative justice, inevitably contradicts the grounds, contents and functions of social rights, impoverishing the complexity of social justice. That is why, in my view, we could (and should) align human and fundamental rights with the scales of justice of N. FRASER, i.e., conceiving of them as instantiations and sources of recognition, redistribution and participation.

4. Accordingly, social rights ${ }^{29}$ seem to me as the best choice to constitute the cornerstone of an emergent new ius gentium socialis ${ }^{30}$, able to offer the established body of legal insight correspondent to the accepted wisdom about the law of nations and operating effectively in positive and critical modes, both as inspiration for domestic law and as aspiration for a uniform body of transnational law, operating effectively in both positive and critical modes (J. Waldron) ${ }^{31}$.

In order to support such a proto-constitutionalised transnational public social law we must commit ourselves to an enterprise of empirical investigation and normative justification composed of three basic endeavours - historical, comparative and ethical - which can generate a constitutively transformative exposure to alterity and difference, also readable as an encounter with strangeness, an experience of absence and the rehabilitation of alternatives ${ }^{32}$.

These diachronic, synchronic, transcendent and/or transcendental exercises and their findings may be reassumed and synthesized within culture, taken, at first instance, as a Bezirkt (in heiddeggerian terms): a fertile territory for questioning

\footnotetext{
29 Andreas FISCHER-LESCANO/Kolja MÖLLER, Der Kampf um globale soziale Rechte: Zart wäre das Gröbste, Verlag Klaus Wagenbach, 2012; Roland KLAUTKE/Brigite OEHRLEIN (Hrsg.), Globale Soziale Rechte: Zur emanzipatorischen Aneignung universaler Menschenrechte, VSA Verlag, Hamburg, 2008; Thomas GIEGERICH/Andreas ZIMMERMANN, Wirtschaftliche, soziale und kulturelle Rechte im globalen Zeitalter, Duncker \& Humblot, Berlin, 2008. In what concerns Europe and the UE, in special, v. Julia ILIOPOULOS-STRANGAS, "Soziale Grundrechte", in Detlef MERTEN/ Hans Jürgen PAPIER (Hg.), Handbuch der Grundrechte in Deutschland und Europa VI/1: Europäische Grundrechte I, Volume 6, CF. Müller, Hüthig Jehle Rehm, Heidelberg/ München/ Landsberg/ Frechen/ Hamburg, 2010, pp. 299 and ff.; Eberhard EICHENHOFER, "Soziale Rechte", IBIDEM, pp. 825 and ff; Christine LANGENFELD, "Soziale Grundrechte", IBIDEM, pp. 1117 and ff.; Thorsten KINGREEN, "Soziale Grundrechte” (\$18), in Dirk EHLERS (Hrsg.), Europäische Grundrechte und Grundfreiheiten, De Gruyter Lehrbuch, 3. Auflage, Walter de Gruyter, 2009., pp. 640 and ff.; Cécile FABRE, "Social Rights in European Constitutions", in Gráinne de BÚRCA, Bruno de WITTE (Eds.), Social Rights in Europe, Oxford University Press, Oxford 2005, pp. 15-28.

${ }^{30}$ Of a meta-regulatory kind, according to some (N. WALKER, B. S. SANTOS).

31 Jeremy WALDRON, "Foreign Law and the Modern Ius Gentium", in Harvard Law Review, Vol. 119, No. 1, Nov. 2005, pp. 129-147; IDEM, "Ius Gentium: A Defense of Gentili's Equation of the Law of Nations and the Law of Nature" (2008), in New York University Public Law and Legal Theory Working Papers. Paper 99: http://lsr.nellco.org/nyu_plltwp/99.

32 I can think of several alternative strategies of ethical foundation/justification, stemming from the ethics of recognition (A. HONNETH, P. RICOEUR), to the ethics of psychanalisis (J. LACAN, F. DOLTO, J. KRISTEVA), passing through the ethics of discourse and communication (H.-O. APPEL/J. HABERMAS), the ethics of alterity (E. LEVINAS, K. E. LØGSTRUP), difference (J. DERRIDA) or commitment (S. CRITCHLEY). On foundations of law, see, for all, U. ROTTHLEUHNER, Foundations of Law (Treatise of Legal Philosophy and General Jurisprudence, Volume 2), Springer, 2007.
} 
meanings and their utterances (albeit not necessarily in a culturalist way), but, not least, to unveil and engender them through an exposure to (Da-sein) and care for the world (Sorge) and the others who share it with us (Mit-sein). To this purpose, a clear understanding of culture is of the essence, having much to benefit from the most recent studies on the subject, whatever the valence, dimension or significance they choose to privilege (structural, mental, functional, normative, behavioural, historical or topical).

Admonished to the need of handling carefully the dangerous C-word, one must recall its richness, while, at the same time, trying to prevent some of the most frequent misinterprations that it permits. To that end, we rely on cultural studies and other scholarly traditions (based upon ancient, medieval and modern classics and specifically developed by authors like M. Arnold, T.S. Eliot, R. Williams, or - more recently - T. Eagleton, Z. Baumann, G. Lipovetsky, M. Antunes, E. P. Coelho, Bragança de Miranda, etc).

More than a simple concept, we should think of culture also as structure and praxis (Z. Baumann). Culture can mean a particular form of life, the activity and the result of aesthetic creation (with a peculiar transformative nomos, stressed by Marcuse) and a reference to critical utopia whether individual or collective ( $T$. Eagleton). Thus, it always enables and constrains simultaneously - even in today's liquid world (Z. Baumann) -, acting as an ideal and a boundary at the same time (R. Geuss).

Culture combines memory, transformation and diversity, i.e. tradition, innovation and pluralism (Häberle). It does not restrict itself to high culture, or popular and mass culture, comprising, as well, marginal, alternative, sub-, anti- and counter-cultures.

This is the place of antinomies and paradoxes dialectically energized, whereby identity and alterity have to dialogue, singularity and universality are shortcircuited, material and spiritual dimensions become substantially entangled. All these linkages and connections are mediated by man himself (and by his autonomous representations, projections and transfigurations). This is so, because of culture's radical embodiment in human anthropological features, acting as a bridge between the somatic and the semiotic or symbolic; signalizing the conditions than enable us to transcend nature trough culture, to transcend culture through our individuation process, only to be confronted with the inner (or collective) unconscious, where the cultural projection of the super ego is shaped as the natural figure of the progenitor - the father - and where the unspoken, ineffable and dark regions of our nature are said to have linguistic structures (J. Lacan).

Strangers to ourselves (J. Kristeva), and estranged from the world (P. Sloterdijk) we come closer to the other, the stranger (S. Zizek, T. Eagleton). Distanced from ourselves and the world, displaced from our common ground, diverted from others, we are united in the experience of difference and enabled with the capability for difference, the ability to differentiate and to differ (J. Derrida); culture is all about founding, finding, producing, negotiating, transgressing and remaking principles and criteria of difference and sameness. Intrinsically dialectic, it presupposes divergence, which explodes in conflicts but allows productive communications.

Post-metaphysical thinking is not necessarily dragged into the void, when construed upon the personal and social intervals (S. Lash), along the alluded fissures, in between the breaches of what were once the holistic thick conception of nation culture, the solid ontological notion of personal identity, and the mechanical understanding of our bodily nature. 
Thus, culture is also about differences, strangeness, intervals, interstices, which undermine the totality of immanence thanks to the ontological and discursive possibility $^{33}$ and ethical freedom, without which responsibility would not be thinkable or practiced; it offers the basic foundation and abyssal ground (Ab-grund) for possible binding projects, since it is the ultimate reason for radical attentiveness, responsiveness and positive hospitality towards the other (as principium of infinity and transcendence, requiring omissions and actions).

As fertile ground, propitious arena and crossroad or axis between past, present and future, individual and collective, person and community, facts and values, it is the locus of mediations (inter), namely between men (intersubjectivity). But it is also transsubjective.

Could we dare to assert that culture is inherently inter-cultural because of its intervals, interstices, intermediations, interconnections, intersubjective basis? Or that it is even (horizontally and vertically, figuratively speaking) trans-cultural, inasmuch as it surpasses itself, overwhelmed by an excess of presence, or driven by the positive impulse of absence and the appeal of the alternative?

Whatever the answer is, culture interests us while it gives access to human selftranscendence. As we will later see, it is always inter and transcultural in more than one sense.

5. The relationship between law and culture takes place at different levels from the axiological to the ontological or the epistemological one. It is no wonder, then, that it has always attracted philosophers, sociologists, anthropologists or linguists throughout the times. This is not the place or time to disclose personal assumptions about the subject. It suffices to say, for now, that my reflections were nurtured by the works of very different authors, like D. Nelken or R. Cotterell, C. Geertz, D. Rosen, N. Rouland, and W. Fikentscher, R. Smend, H. Heller, P. Häberle, M. Reale, M. V. Hoecke, etc. These authors taught us that culture has its own laws, that culture can become law (i.e. normatively binding), that cultural activities and products are objects of law's protection and promotion; and that law, for its part, is also culture and part of culture(s), for it develops a partially autonomous culture and contributes to the more general cultural production and reproduction.

Peter Häberle reminded us that democracy and the rule of law are cultural creations, integrating an archetype of political organization transformed in a civilizational heritage or legacy assumed and accepted with future pretensions something to preserve and to improve, a nest of memories and hopes connected by responsibility: the responsibility of a holder and a performer. The constitution is the expression of a certain degree of cultural development, a way of selfrepresentation peculiar to a people, mirror of its cultural legacy and ground basis or foundation for its hopes and desires. Constitutions are, in form as in substance, an expression and an instrument of cultural mediation - receptive, reproductive, but also transformative (as a repository of future configurations, experiences, and knowledge).

From the other side of the Atlantic, one can hear J. Balkin's inspiring voice, stating that The constitution is a set of political institutions, a source of values and aspirations, a repository of cultural memory and a transgenerational political project.(... ). But if the

\footnotetext{
33 Whose ethical corollary is R. Kearney's non finalistic eschatology of justice - Richard KEARNEY, Poétique du Possible: Vers une Herméneutique Phénoménologique de la figuration, Beauchesne, Paris, 1984.
} 
Constitution belongs to the American people, it also helps constitute them as a people that persists over time. It does so by constituting a common project, a common past, and a common destiny ${ }^{34}$.

However, if law is inter and trans-subjective, whilst radically based in inter- and trans- constitutive dimensions of culture itself, then it seems even more inter and transcultural when we take notice of horizontal constitutional dialogues, exchanges, mutual observations, reciprocal learning and dialectical transcendence across countries, nations, languages, etc. As culture becomes intentionally and problematically intertwined, the self-transcendental conditions and selftranscendent references of communities, collective subjects or inter- and transindividual realities (from Popper's Third World), reveal themselves closer (to one another) than one would expect; something which evidently could not go without serious juridical implications.

Nevertheless, it is legitimate to ask if the normative reality of constitutional public social law can be thought of in such terms? If culture is not an answer but the possibility of a question, an explosion of meanings, providing explanations and justifications, rationally and reasonably - i.e., convincing, and thus recognizable as binding -, should constitutionality be seen as inter and transconstitucional?

My hypothesis is that inter and trans-culturality are practically stimulated by new international and transnational phenomena, but these only reinforce something already existent in any culture. In my opinion, inter- and transconstitutionality highlight cultural-juridical differences while also creating bounds, approaching professionals, organizations, institutions, people and communities at an unprecedented pace. Some think pragmatically and consider that only contingent overlaps can result from these interactions. Others suggest that these synergies work out at other levels, allowing for normative justifications and important findings of valid and effective foundations and criteria.

To maintain a realistic and prudent attitude in front of these empirical phenomena, there is no need to give up on questioning their deeper meaning. Perhaps an inter- and trans-cultural perspective can thoroughly depict and illustrate more accurately our current constitutional moment. I would even dare to suggest, that it could benefit from an appropriate embedding within a broader (though intentionally juridical) theory of inter- and transculturality. Human social rights and the public/common (as different from privatized and individualized) institutions inspired and informed by them, might emerge, then, as expressions of a reasonable project of justice, legitimating claims to binding authority, due to inter-cultural and transcultural foundations.

With that in view, we must start by giving a brief account of the new interconstitutional and transconstituional theories.

\section{Interconstitutionality and Transconstitutionalism}

6. At least among Portuguese-speaking juridical literature, the expression interconstitutionality made its first, timid appearance, in a fascinating little book written by F. Lucas Pires (one of our European law pioneers), which bore an emblematic title: Introduction to Constitutional European Law. The year was 1997, and the reference made by the late professor was very brief, and allusive, almost ciphered (in P. Rangel's words); nevertheless, it was interesting enough to be

\footnotetext{
${ }^{34}$ Jack BALKIN, "Original Meaning and Constitutional Redemption", in Constitutional Commentary, Vol. 24, 2007.
} 
caught in the radar of some scholars, such as João Loureiro ${ }^{35}$, who took notice of it, in early 1999, drawing Paulo Rangel's attention to the subject ${ }^{36}$.

For Paulo Castro Rangel, this theory does not aim to overcome and supersede the idea or concept of constitution and the epistemic horizon it defines, envisioning the ambitious objective of giving birth to some sort of new constitutional theory, rooted on (and fed by) the dynamics of planetary constitutional life. Nevertheless, although keeping itself within the traditional canons of constitutional theory, it pleads for a renewal of the concept of constitution, which supposedly should no longer be associated with the State, but rather be adapted to the new postwestphalian Lebenswelten ${ }^{37}$. The same is to preach for a shift of constitutional references - from the State to the more and more polymorphic notion of political community; a political community increasingly polyarchic, whose members wind up being plural persons, animated by several contradictory feelings of belonging, and socially framed and constructed by the multiple citizenship statutes that enable them to participate in different societal spheres. At the end of the day, Rangel favours a return to the theory of constitution and to constitutional law, though taken in a new interconstitutional conception.

7. a). The new Denkfigur would have to wait for Gomes Canotilho to receive its much deserved development and elaboration. The Professor from Coimbra, masterfully recoiled it and worked it out, patiently carving and shaping the rough stone into a shining and more presentable little diamond, by building up a complete theory of interconstitutionality as interculturality, which came to be our major source of inspiration $^{38}$.

Taking into the right account the proliferation of constitutional paradigms, since the dawn of this new century, Gomes Canotilho soon expressed his preference for a theory of interconstitutionality to the detriment of other competing conceptions (such as multilevel, cooperative, multidimensional or federalist constitutionalism ).

Borrowing some of Paulo Rangels' hermeneutic variations around Lucas Pires' work, Canotilho interconstitutionality theory dwells into the interconstitutional relations of competition, convergence, overlapping and conflict of manifold constitutions and several constituent powers within the same political space evoking, as historical precedents, the medieval landscape of juxtaposed jurisdictions, statutes, criteria and sources of law, and the more recent and vivid experience of federal states and confederations,

\footnotetext{
35 To be more precise, João Loureiro had already used the term within a former project of $\mathrm{PhD}$ dissertation presented in Germany and inspired, at the time, by Karl Otto Apel's Discourse Ethics.

${ }^{36}$ F. Lucas PIRES, Introdução ao Direito Constitucional Europeu, Almedina, Coimbra, 1997; Paulo Castro RANGEL, "Uma Teoria da «Interconstitucionalidade» (Pluralismo e Constituição no Pensamento de Francisco Lucas Pires), in Themis, ano I, n. ${ }^{\circ}$ 2, 2000, pp. 127-151; J. J. Gomes CANOTILHO, Brancosos” e Interconstitucionalidade - Itinerários dos Discursos sobre a Historicidade Constitucional, Almedina, Coimbra, 2006; João LOUREIRO, “《É bom morar no azul»: a constituição mundial revisitada", in Boletim da Faculdade de Direito, Volume 82, 2006, pp. 181-212.

${ }_{37}$ Paulo Castro RANGEL, "Uma Teoria da «Interconstitucionalidade» (Pluralismo e Constituição no Pensamento de Francisco Lucas Pires)", op. cit., (sic).

38 J. J. Gomes CANOTILHO, "Interkonstitutionalität und Interkulturalität", in Alexander BLANKENAGEL/Ingolf PERNICE/Helmuth SCHULZE-FIELITZ (Hrsg.), Verfassung im Diskurs der Welt. Liber Amicorum für Peter Häberle zum siebzigsten Geburtstag, Mohr Siebeck, Tübingen, 2004, 83 s.); IDEM, Direito Constitucional e Teoria da Constituição (Capítulo 3, do Título 3, da Parte V), Almedina, Coimbra, 7.ª edição, 2003; IDEM, Competência Intercultural e Interjusfundamentalidade Master na Faculdade de Direito de Coimbra, polic. Coimbra, Ano lectivo 2008/2009); IDEM, "Estado de Direito e Internormatividade", in Alessandra SILVEIRA (Coord.), Direito da União Europeia e Transnacionalidade, Lisboa: Quid Juris, 2010, pp. 171-186.
} 
with their inner articulation and interactions among States or States and Federation.

Even though he originally had the EU in mind, the reach and range of his writings are potentially much wider. After all, under this theory, although preserving their autodescripitive and autoreferential functions, as well as their value, Constitutions are constrained to "leave the castle and descend into the net of constitutions and constituent powers" with different sources and legitimacies. Thus, the theory of interconstituionality can be described as a specific form of political and social interorganization. Nevertheless, were interconstitutionality to be looked upon from a mere interorganizational perspective and it would most certainly leave unexplained the powerful and valuable role of integration played by Constitutions. That is why it culminated in a theory of constitutional interculturality, at the hands of Canotilho, for whom interculture means precisely the sharing of culture, ideas, Weltanschamungen and visions about ourselves and the others. Interconstitutional communication sets is feet on common principles that point out to the idea of cultural constitution and cultural constitutional state, as proposed by P. Häberle ${ }^{39}$.

Interconstitutional interactions, exchanges, overlaps, entanglements and fusions bring about the problem of paradigm articulation. Linking paradigms inside the intercultural net then implies some sort of interparadigmaticity.

Finally, interconstitutionality suggests moments of intertextuality and intersemioticity, in the sense that it does not dispense the investigation and discovery of a set of rules regarding the production and interpretation of constitutional texts and the discourses and social practices related to them; a methodological concern easily justified by the growing necessity to ensure comprehensive justice amidst plural communities where different conceptions of good are under dispute ${ }^{40}$.

More recently, Canotilho expanded his theory, to capture the new schemes of interjuridicity, internormativity, interjusfundamentality and interjurisdictionality, developed at the European level. In point of fact, European internormativity demands the questioning of the viability and meaning of an alleged rule of law beyond the State, especially when compared to alternative regulatory proposals (like good governance) ${ }^{41}$.

Bearing in mind that the rule of law reclaims not only the prevention of arbitrary use of power, by imposing binding rules, but also the creation of the necessary conditions for the transformation of these rules into constitutive dimensions of a true system of law (structured in a normative set of rules of action, conduct and control), Canotilho realizes that this new paradigm of rule of law, detached from the State, has been emptied of and that it seems indifferent (if not impermeable) to democratic and constitutional substance and material dimensions

\footnotetext{
39 Constitutional culture leads back to the complex of attitudes, ideas, experiences, patterns of value, expectations, actions and objective conducts of citizens, plural groups and state organs, referred to the Constitution as Offentliches Prozess. Interculturality begins as a communicative partake of such values and ideas, concretely translated into non juridical forms, to end up making tendential normativization possible. It is worthy to mention that despite this cultural tone (or flavour), Canotilho moved away from excessively particularized conceptions of culture taken as an integration concept (W. Brugger). Inscribed in one of the most inspiring constitutional lineages of constitutional law - having studied, together with Peter Häberle, under Konrad Hesse's orientation (a notable disciple of Heller and Smend) -, he proposes a complex concept of culture, charged with intercultural dimensions (similarly postulated - without using the prefix inter - by Peter Häberle).

${ }^{40}$ See J. J. Gomes CANOTILHO, Direito Constitucional e Teoria da Constituição, op. cit.

${ }^{41}$ J. J. Gomes CANOTILHO, "Estado de Direito e Internormatividade”, op. cit.
} 
of justice, based on the protection of personal, democratic and social rights, as well as freedoms and guaranties ${ }^{42}$.

Consequently, a disturbing question remains in the air: to know whether it is possible to conceive the transnational rule of law as a material axiological parametrical structure, standing above the different positive juridical orders normatively interlaced.

b). Notice that authors like J. Tully, J. Habermas, and Boaventura Sousa Santos ${ }^{43}$ also walked along the wide path of interculturality, the first one advocating for a post-imperialist, high-enlightenment, dialogic and inclusive philosophy of human rights, the second one disserting about Der interkulturelle Diskurs über Menschenrechte, and the last one fighting for a counter-hegemonic policy of human rights served by a diatopical hermeneutic ${ }^{44}$.

8. Directly influenced by Canotilho, the Brazilian Bruno Galindo ${ }^{45}$ also pleads for an intercultural theory of constitution, in order to cope with the transformations operated in constitutional law as a consequence of supranational integration within the EU and the Mercosul. His assessment is epistemic, electing, as object, the constitutional interculturalism phenomenon, whilst clearly differentiated from what he dubs Intercultural constitutionalism, since the latter encompasses the dialogue between the different cultures co-existing within a society (and is hence connected to the idea or ideal of a Culturally inclusive constitution) whereas the former implies the recognition of constitutional cultures diversity (whether from ideological, systemic, or national point of view) and projects a dialogic relationship between them, fostering each constitutional culture's conscience of its own imperfection and the willingness to find out cooperative solutions.

In a brief taxonomy, he delineates three dichotomies: from an ideological standpoint, social constitutional cultures can be liberal and social; from a systemic point of view, one can speak of civil law and common law constitutional cultures. Finally, he finds it possible to discern two constitutional cultures still in the process of formation: nihilistic and supranational.

The intercultural theory of constitution hinges on the critical rationalism of Karl Popper and the Möglichkeitsdenken adduced by Peter Häberle, and therefore exhibits critical, open, pluralistic, universalistic and contextual theoretical credentials.

\footnotetext{
42 IBIDEM.

43 Boaventura de Sousa SANTOS, A Gramática do Tempo: para uma nova cultura política, Edições Afrontamento, 2006; Jürgen HABERMAS; "Der interkulturelle Diskurs über Menschenrechte”, in Hauke BRUNKHORST et alii (Eds), Recht auf Menschenrechte: Menschenrechte, Demokratie und internationale Politik, Suhrkamp Verlag, Frankfurt aM, 1999, pp. 216-227. James TULLY, Strange Multiplicity: Constitutionalism in an Age of Diversity, Cambridge University Press, Cambridge, 1995

44 There are 5 premises for the transformation of human rights into a subversive/insurgent cosmopolitan project: 1. Overcoming the universalism/relativism debate (trough intercultural dialogues about isomorphic concerns in that is converging preopcupations, even if seen from different worldviews and expressed in disparate languages - against universalism; criteria against relativism) and recognizing that: 2. All cultures have their own conceptions of human dignity, altought they aren't necessarily formulated in terms of human-rights; 3. All cultures are cincomplete and problematic in their conceptions on human dignity; 4. No culture is monolytic; 5. All cultures tend to distribute people and grous between two competittive grous of herarchical belonging equality and difference. We have the right to be treated as equals whenever difference makes us inferior, and the right to be treated as different when equality de-characterizes us.

${ }^{45}$ Bruno GALLINDO, Teoria Intercultural da Constituição (A Transformação Paradigmática da Teoria da Constituição Diante da Integração Interestatal na União Européia e no Mercosul), Livraria do Advogado, São Paulo, 2006.
} 
9. Not satisfied with the preceding theories, the Brazilian professor M. Neves commended an alternative approach, baptized as transconstitutionalism ${ }^{46}$. In his opinion, the conceptual galaxy of interconstitutionality is doubly restrictive. On the one hand, because it allegedly gives the impression that only horizontal relations between equal juridical orders are taken into account, therefore leaving untouched the essentials of the traditional constitutional paradigm ${ }^{47}$. On the other hand, for the reason that so embedded it was in its European context that it probability would prove useless if transplanted to any other environment.

Transconstituionalism, in its turn, can be systematically exposed, closely following the arguments and formula of M. Neves.

i. Notion.

In the author's own words, Transconstitutionalism designates the interlacing of diverse normative juridical orders, state or transnational ones, international and supranational around the same problems of constitutional nature - i.e., problems connected to / related with/concerning human rights and the limitation of power, which are discussed, at the same time, by courts pertaining to/ integrated in different normative orders.

\section{ii. General framework.}

M. Neves never despised the constitution in its quality of basic instance for the normative self-foundation of the State as a territorial political and juridical organization. Nevertheless, from his perspective, even though the traditional state constitutional law, generally connected to a foundational text, cannot be dismissed, constitutionalism has opened itself and spread beyond state boundaries, not exactly because new non state constitutions emerge, but instead due to the fact that constitutional problems, especially those concerning human rights, cut across/ very different juridical orders, which operate in an interwoven sort of way in their search for solutions.

Hence, transconstitutionalism must not be confused with other - seemingly similar - terms and concepts, such as international, transnational supranational, state or local constitutionalism. According to the author, the concept very clearly points out to the emergence and development of juridical problems, which cut across and run through very different types of juridical orders. Thus, a transconstitutional problem implies a question that can involve state, international, supranational and transnational courts, but, not the least, local juridical institutions. They work separately, each one striving in search of a solution, mainly due to the inexistence of rules defining attributions, competences and ambits of jurisdiction. In situations like these, whether there are no secondary rules to solve the conflict of competence among the several intervening courts, or, when existent, they are not consensually backed up by adjudicatory organs.

iii. Typology.

Supported by extensive examples M. Neves advances a typology of transconstitutional manifestations, which basically divides them into two groups.

On the one hand, stands transconstitutionalism between two juridical orders, namely between state law and international $\mathrm{law}^{48}$, between supranational and state

\footnotetext{
${ }^{46}$ Marcelo NEVES, Transconstitucionalismo, Martins Fontes, São Paulo, 2009.

47 Interconstitutionality would be nothing more than a constitutional conflict law, disregarding the late transformations this subject-matter has undergone.

48 Internationalism and nationalism should be discarded as they represent a serious menace to human and fundamental rights. The examples of transconstitutionalism among international and state orders show us the need to overcome the parochial treatment of constitutional problems by the states, without necessary leading to some unjustifiable belief in international law as ultima ratio,
} 
law (EU), between state orders (illustrated by the debate in the USA), between state and transnational orders (lex mercatoria, lex sportiva, lex digitalis) and between juridical state orders and local extra-state ones (of native communities) ${ }^{49}$

On the other hand, there is a more complex multi-angular transconstitutionalism between orders of the same species and orders of very different sorts, connected through a common reference to the same juridical problems and which has become a trademark of a worldwide multi-level and multi-centred juridical system characterized by tangled hierarchies (Hofstaedter) ${ }^{50}$.

This is particularly evident in relation to what Marcelo Neves names the pluridimensional transconstitutionalism of human rights. Controversies regarding human rights normally derive from the fact that diverse normative orders of the new juridical multi-levelled world system hold different understandings of questions about human rights, with some of them even denying the existence of universal human rights. In this context transconstituionalism gains a special significance, by cutting through different kinds of juridical orders, fostering cooperation and overcoming collisions at the same time.

From this standpoint - and allow me to paraphrase the author - the most adequate path appears to be that of an engagement model, or better put, that of transversal entanglement between juridical orders, in such a way that each and every one of them will proclaim itself capable of permanent self-reconstruction through continuous learning by/with experiences from the other juridical orders also interested in solving the same juridical and constitutional problems of fundamental human rights.

iv. Methodology.

Transconstitutionalism stands out as the constitutional law of the future (sic), demanding an increased degree of interdisciplinarity, and, in that sense, asking for a specific methodology based on normative and cognitive openness, containment, communication and mutual learning, self-transformation and transversal rationality.

Indeed, to absorb the original dissent, one must not ingenuously try to abandon or suppress identities, avoiding reciprocal blockages between conflicting or intertwined orders. On the contrary, constitutional identity is constantly reconstructed through ongoing dialectics with alterity. Methodically speaking, optimization clearly loses to self-restraint, not as an end in itself but as a consequence of double contingency and the capacity to be surprised by others, accepting an open future, which escapes predefinitions drawn by any of the orders involved (M. Neves). To strengthen its own capacity to offer reasonable solutions to common problems, each order should be ready to search for the other's normative discoveries.

Space is thus opened up for the development of a transversal rationality (imported - in a somehow counterfeited version - from W. Welsch) across the triadic relations between principles and rules (principle-principle, principle rule and rulerule).

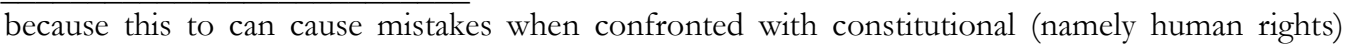
questions

49 The brasilian example of the Yanomami epythomises the dangers of succumbing to the temptation of human rights imperialism - invalid from an anthropological-political and anthropological juridical viewpoint, but, not less, from the specific point of view of one sensitive to transconstituionalism constitutional law.

${ }^{50}$ Notwithstanding the hierarchy of the different orders involved, the heterarchical relations among them tend to prevail. (M. Neves)
} 
This is a method of reciprocal stimulation of different orders towards selftransformation able to make them more and more prone to constitutional dialogue. Neves sees it as the most adequate way to ensure the difficult passage from simple de-structured fragmentation to constructive differentiation, winning over definitive hierarchical methods (whether international, national, supranational, transnational or sub-national and local). Neither hierarchical methods nor sheer capitulation before fragmentation can offer satisfying solutions. The Brazilian professor ascertains that transconstitutionalism is expected to build transitional bridges, enabling more constructive relationships between juridical orders, by means of a pluridimensional articulation of their principles and rules in face of common juridical-constitutional problems, dependent on solutions which can be deemed bearable by all the orders involved, without relying on an ultimate authority or instance of decision. More than authority, transconstitutionalism claims for method (sic).

\section{v. Limits and possibilities of transconstituionalism.}

M. Neves cautiously tries to indicate the possibilities and limits of transconstitutionalism, taken as a response to the functional demands and the normative claims or pretences of today's global society and in face of its empirical conditions of fulfilment and development.

As for the latter ones, the diversified means/modes of relationship between the primary difference-code of law (in temporal, social, material and territorial dimensions) and the programs and juridical criteria of decision and solution, tends to highlight the asymmetries of legal forms, exposing the dangers of oppression it can represent for the weakest ones.

From a functional-systemic point of view, concentrated on the relation between problems and solutions, Transconstitutionalism serves as a structural model of functional connection between the functionally differentiated spheres of global society - beyond constitutional teleological utopia and sheer resignation in front of societal fragmentation - by promoting the stable structures required by a differentiated order of communications, transversally networked - which is to say, obtaining systemic integration, thus obviating normativist or realist overloads.

With respect to the normative claim for counterfactual stabilization of expectations within the world society, transconstituionalism has the ambition of being and acting as a normative counterpoint whether in relation to the expansive social primacy of cognitive structures (economical, technical and scientific), whether with respect to the semantic of control of information and knowledge by the media, not incurring in the antipodal error of moral communitarianism. The alternative to hegemony cannot be the utopia of purely moral community, because the latter is based on social relationships of membership and solidarities around the sharing of common values - whereas from Neves's point of view, what we find in social reality are systems of communications, games of languages, groups and persons very different from each other, in an heterogeneous confluence of interests, values, and expectations. Regardless of its subsisting communitarian formations, the global society cannot be portrayed as a political community, without provoking some serious theoretical and practical disasters. So what is to be demanded from society is not membership or community but promotion of generalized inclusion (access to the benefits of functional systems) or the reduction of the ever increasing primary exclusion.

The different juridical orders entangled in the solution of a constitutional problem should look for transversal ways of articulation, each one observing the 
other(s) so as to understand its own limits and possibilities, and therefore contribute to the solving of the problem My blind spot can be seen by the other ${ }^{51}$.

10. Persuasive as it may be, we're talking about one of the many (possible) points of view on the subject. Let us not forget, then, that transconstitutionalism can also lead, for example, to a broader notion of transculturality with objective (W. Welsh, M. Cannevacci) and subjective (N. Rouland, Sarhan Dhouib) facets.

Effectively, aside from anthropological and sociological studies on transversal or common goods, values, principles, rules and institutions, we find prolific transcultural research on human rights, conducive to solidarity, in the words of Rouland $^{52}$. The famous anthropologist defends a universal and transcultural declaration of human rights, praising Panikkar's idea of homeomorphic notions of rights $^{53}$.

\section{From Inter and Transculturality to Inter-and Transconstitutionalim (and back again...).}

Since this paper is not the occasion for a circumstantiated analysis of all the vexing questions thrown up by the aforementioned complex issues, I will only draft here the main lineaments for a possible theory of inter and transconstitutionality of inter and transcultural flavour, systematizing the materials conveyed, and leaving some hints for further studies ${ }^{54}$. The needed critical reflection on interconstitutional and transconstitutionalist main thesis will be put aside for the moment.

11. I believe it would be advisable to start by comparing and distinguishing multi-, inter- and transculturality among themselves and in relation to their respective hypertrophies - multiculturalism, interculturalism and transculturalism and then to proceed with an inventory of their implications at the philosophical, theoretical, methodological, dogmatic and practical levels of law.

This would enable us, for example, to capture multiculturality's attitude of homologation of the existing cultural differences ${ }^{55}$, under the cover of an (acritical) politics of recognition, always at the verge of sliding into multiculturalism and its passive acceptance or irresponsible celebration of entrenched collective identities (supposedly holistic, homogeneous and, in any case, internally opaque), organized within one society (and thus, in most cases, stately referred) ${ }^{56}$.

Interculturality also proceeds from a conception of cultures as islands, but it can overcome it through inter-observation, intercommunication and interaction. Differences here give rise to conflicts, but also conversations, due to the relationality underlying the concept.

\footnotetext{
51 I tend to agree with P. C. Rangel, preferring the use of the term transconstitutionality, which seems to evoke a framework narrative for the new problems challenging constitutional law and constitutional theory, instead of transconstituionalism, which apparently denounces the commitment to a particular (and thus more narrow) perspective of solution, based on an historically located/situated concept of constitution. After all, constitutionalism designates a specific ideological and political movement, associated with a particular material concept of constitution - that is, a constitution with certain and particular content.

${ }^{52}$ Norbert ROULAND, Nos Confins do Direito, op. cit.

53 For a glossary of the most important concepts of Panikkar's work: http://www.raimonpanikkar.org/ english/glossary.html

54 See the references on note 1.

55 The allegory of the salad bowl (instead of the melting pot).

${ }^{56}$ Leading to ghettoism and separateness.
} 
Transculturality drives even further ; on one hand, it discusses the possibility of crossing borders, (cutting through cultures and internally interweaving them, according to Transversale Vernunft), and, on the other hand, rediscovers and constitutes new limits and thresholds and enriches the transcendent tertia presupposed by comparisons and dialogues.

Understandably, the preference for one of these perspectives will necessarily shape the way we conceive the law's existence, contents, enforcement, methods and rationality and also influences how we come to understand the juridical thought itself. To give an example, the first perspective will tend to depict law as a communitarian ethos, multiplied by the different cultural identities of a determined referential social and political space, thus forming a sum of parallel incommunicable orders articulated through a sheer principle of tolerance, with different values as substratum and substance, and enacted by disparate institutional authorities or social actors, according to their communities self-representation and conception of law's methodology. It would be very different, however, to think about it as agonistically based, or built upon original consensus or cooperative processes of mutual understanding, dialogically structured and instantiated and dialectically enacted; not to mention, to consider it as the expression of transversal communalities, dialectically constitutive of horizontal subjectivities and transversal institutions.

12. Leaving the multicultural paradigm aside, we should turn our attention to interculturality, using the works of Hamid Yousefi and Franz Zimmer ${ }^{57}$ as general background; Special attention must be paid firstly to an author to whom we owe one of the most complete and vehement attempts to elaborate on an intercultural paradigm, comprising several dimensions like Interkulturelle Geschichtstheorie, Interkulturelle Tolerans, Interkulturelle Kulturtheorie, Interkulturelle Religionswissenschaft, Interkulturelle Vernunft and Interkulturelle Globalisierung.

The analysis should be displayed along four parts: the first one dedicated to the juridically relevant features of interculturality - interoganizationality, interparadigmaticity, intertextuality, intersemioticy and internormativity; the second, dwelling into general internormativity; the third already circumscribed to interjuridicity, its mode of existence (validty and effectiveness), normative modalities (intersubjectivity and the interjusobjectivity); sources of law and juridical principles and diverse criteria (legal, judicial, doctrinal, social, etc.); the last one, would be devoted to interconstitutionality and particularly attentive to intersociality and interpublicity.

After all, ours is a world of intensive and extensive networking organizations (economic, political, and social), with their own cultures, and very different cultural backgrounds; a world which texture is made of multilingual texts (especially in law), infinite local, regional, state, and universal narratives, world classics of literature, communities of interpretation and translation and so on.

No wonder normativity itself tends to emerge as complex interweaving of principles and rules, orientations and patterns, standards and guidelines that we considerably abide to, in our social contexts and respective interactions.

\footnotetext{
57 Franz ZIMMER, "Is Intercultural Philosophy a New Branch or a New Orientation in Philosophy?”, in Gregory D'SOUZA (ed.): Interculturality of Philosopby and Religion, National Biblical Catechetical and Liturgical Centre, Bangalore, 1996, pp. 45-57 (http://homepage.univie.ac.at/franz.martin.wimmer /intpheng95.pdf); Hermann-Josef SCHEIDGEN/ Ina BRAUN, Interkulturalität - Wozu? Hamid Reza Yousefi und P. Gerdsen im Gespräch, Verlag T. Bautz, Gmbh, Nordhausen, 2011.
} 
As for juridicity, the question arises when can it claim true cultural existence, in an intercultural scenario? What are its subjective and objective expressions, and how do they relate to one another, when they stand against an intercultural paradigm? Where does law come from? How do the juridical authorities from different contexts communicate? What is the meaning of legislative cooperation among states, of international judicial dialogue, of academic exchange? How do principles and criteria circulate among cultures and are gradually recognized, informing external and internal legal cultures and social practices in general? What is to say about methodological borrowings, importations, migrations, transliterations, translations, $\mathrm{etc}^{58}$ ?

13. Interculturality, well understood, will take us to the transculturality paradigm, which, I believe, can give us important keys for the rediscovery of commonalities and the reinvention of solidarities.

13.1. Transculturality ${ }^{59}$ refers to cultural mixing and interpenetration in a globally connected world, thus implying internal diversity, permeable borders, cultural blending and manifold cross-cultural interactions and linkages.

Transculturality has gradually evolved from the description and assertion of cultural phenomena of horizontal borrowing, blending and bending ${ }^{60}$ to the reckoning of cross-cultural commonalities fostered by two quite different factors operating at different levels. One is the current process of permeation of cultures - a process creating commonalities by overcoming differences. The other is much older, and related to the human condition as such; the discovery of commonalities which precede and underlie all formation of difference ${ }^{61}$.

As a matter of principle, transcultural experience and exchange cannot be understood without assuming something universal underlying cultural difference. In spite of that, we know that reference to cultural universals must reckon with cultural resistance, due to the unparalleled hegemony of difference thinking within

\footnotetext{
58 Paul RICOEUR, "Il Paradigma della Traduzione", in Ars Interpretandi, 2000, pp. 1 and ff.; François OST, Traduire - Défense et illustration du multilinguisme, Fayard, Paris, 2009; Tecla MAZZARESE, "Interpretazione e traduzione del diritto nello spazio giuridico globale", in Diritto \& Questione Pubbliche, n.8, 2008, pp. 88-101; Vlad PERJU, "Constitutional Transplants, Borrowing, and Migrations", in Boston College Law School Faculty Papers. Paper 360. 2012; Michele GRAZIADEI, "Legal transplants and the Frontiers of Legal Knowledge", in Theoretical Inquiries in Law, Vol. 10, pp. 693-714; Sieglinde E. POMMER, "Translation as Intercultural Transfer: The Case of Law", in SKASE - Journal of Translation and Interpretation [online], 2008, vol. 3, no. 1; Mark RADHERT, "Comparative Constitutional Advocacy", in American University Law Review, Vol. 56, 3, pp. 553-665; Vicki JACKSON, "Constitution as «Living Trees»? Comparative Constitutional Law and Interpretive Metaphors", in Fordham Law Review, Vol. 75, pp. 921-960; Peter HÄBERLE, Rechtsvergleichung im Krafketfeld des Verfassungsstaates. Methoden und Inhalte, Kleinstaaten und Entwicklungsländer, Duncker \& Humblot, Berlin, 1992; Peer ZUMBANSEN/ Russel A. MILLER, Comparative Law as Transnational Law. A Decade of the German Law Journal, Oxford University Press, Oxford, 2011; Anne PETTERS, "Universalist Assumptions and Implications of Comparative Law - Should They be Deconstructed?”, in THE AMERICAN SOCIETY OF INTERNATIONAL LAW (Hrsg.), Proceedings of the 93rd Annual Meeting, Washington D.C., 1999, pp. 366-369.

59 The idea of transculturality has obtained increasing aknowledgment and acceptance in a myriad of regional, national, international, supranational and transnational fora, namely in connection with human rights issues.

60 Alasdayr PENNYCOCK, Global Englishes and Transcultural Flows, Routledge, London \& New York, 2007.

${ }^{61}$ Wolfgang WELSCH, "On Acquisition and Possession of Commonalities", Lecture delivered on the occasion of the ASNEL Conference "Transcultural English Studies" at Wolfgang Goethe University Frankfurt/Main, May 19, 2004.
} 
the cultural studies environment ${ }^{62}$. And, in fact, if differences do not vanish, its mode of being is certainly modified. Transculturality does not end up in global uniformity, it rather improves and increases cultural diversity. Differences are continuously being overcome and produced, by transgression of boundaries, negotiation of limits, and transfiguration of realities.

We are talking about an ongoing never-ending process of dialogue between identity and alterity, as well as resemblances and differences, whereby transcultural orientations provide a first set of commonalities and, on this basis, allow for the development of subsequent commonalities, in a dynamic of possession and acquisition of transcultural commonalities. In other words: transcultural intersections lead to an initial acquisition of commonalities, and the possession of these consequently enable further acquisitions. This increased possibility for exchange and coming to terms with each other obviously represents a great advantage in a transcultural constitution.

At the macro-level, as a result of the increasing interpenetration of cultures, there is no longer anything absolutely foreign and nothing exclusively one's own; however, strangeness, alienation and otherness obviously remain, giving an all new meaning to the appeals of hospitality and commensality. Meanwhile at the microlevel, human beings also become cultural hybrids due to the increasingly transcultural process of formation to which they are submitted.

The conditions seem gathered for the elaboration of somewhat innovative philosophies of the subject and the practical realm (politics, society and law), offering some new interesting insights into action, rationality, normativity, actors and agents.

However, to make sense of transculturalism, we have to precise its notion and meaning, to set it apart from confining realities or categories ${ }^{63}$, and to account for (and organize) its main figures and tropes: Transparadigmaticity, Transliteration, Translation, Transnationality, Transculture, Transgression, Transversality, Transrationality, Transsubjectivity, Transcendentality, Transcendence, Transculturality, Transnormativity, Transformation, Transjuridicity, Transtheory, $\operatorname{etc}^{64}$.

62 IBIDEM. See also: Wolfgang WELSCH, "Transculturality - the Puzzling Form of Cultures Today" in Mike FEATHERSONE/ Scott LASH (Eds.), Spaces of Culture: City, Nation, World, Sage, London, 1999, pp. 194-213; IDEM, "Was ist eigentlich Transkulturalität?" in Lucyna DAROWSKA/ Claudia MACHOLD (Hrsg), Hochschule als transkultureller Raum? Beiträge zu Kultur, Bildung und Differenz, transcript-Verlag, 2009.

${ }^{63}$ Like F. Ortiz trans-culturation, other, general, cross-cultural references, or transnational studies and phenomena - besides mere interculturality. Afef Benessaieh distinguishes tranculturation from aculturation, de-culturation and neo-culturation - Afef BENESSAIEH, "Multiculturalism, Interculturality, Transculturality", in Afef BENESSAIEH (Dir./Ed.), Amériques Transcultureeles - Transcultural Americas, University of Ottawa Press, Ottawa, 2010.

${ }^{64}$ With a special concern for the diversity of contributions convoked, v. Sarhan DHOUIB, "Von der interkulturellen Vermittlung zur Transkulturalität der Menschenrechte", in Hans Jörg SANDKÜHLER (Hrsg.), Recht und Kultur. Menschenrechte und Rechtskulturen in transkultureller Perspek.tive, Frankfurt [u.a.], Peter Lang, 2011, pp. 155-178; Andreas HEPP, "Transculturality as a Perspective: Researching Media Cultures Comparatively", in Forum Qualitative Social Research, Volume 10, No 1, Art. 26, January 2009; Robert PÜTZ, "Culture and Entrepeneurship - remarks on Transculturality as Practice", in Tijdschrift voor economische en sociale geografie, Volume 94, Issue 5, pp. 554-563, December, $2003 \quad$ (consultado on-line); Transtext(e)s, Transcultures (http://transtexts.revues.org/index .html); Werner DELANOY/Alpen ADRIA, 'From 'inter' to 'trans' or quo vadis cultural learning??, in M. EISENMANN/ Th. SUMMER (Hrsg.), Basic Issues in EFL Teaching and Learning, Universitätsverlag Winter Gmbh, Heidelberg, 2012, pp. 157-167; Massimo CANEVACCI, "Transculturalidade, interculturalidade e sincretismo", in concinnitas, ano 10, volume 1, número 14, junho 2009; Manju JAIDKA, "India is my country but the world is my 
If we want to theorise transculturality, and draw juridical consequences of it, the semantic cloud speaks volumes about the difficulties of the endeavour. Some ideas are worthwhile to highlight. Thus, while some authors emphasise subversion or assimilation, Pennycock ${ }^{65}$ praises the transgressive and transformational effect of crosscultural mixing and Schulze-Engler addresses the transgressive and transcendent in transcultural thought ${ }^{66}$.

13.2. Walking this road, listening about new forms of transcendence, trans subjectivities, or the horizontal comparisons which presuppose and constantly recreate the pertinent tertia comparationis, we may reassume our intermediate hypothesis, about the possible transcultural dimensions of law's fundamentals and foundations, constitution and existence, dogmatic stabilization and practical enactment.

Law produces transculturality, has its own transculturality, and is certainly a product of transculturality - axiological, epistemological and ontic-ontological. Transcultural subjects of (and subjected to) law, transcultural problems, transcultural assumptions, not to mention the convergence to (and trough) transculturally revealed transcendence (and transcultural principles and criteria), demand maturate investigation and reflection.

The works of M. Neves, Gomes Canotilho and others are of extreme help and should constitute our starting point.

Nevertheless, some cautions are to be borne in mind from the beginning ${ }^{67}$, so as to prevent the misinterpretation of misleading clues, left along the roughly sketched (and quickly glimpsed) tracks of the research. Hence, it is important to stress that, in spite of all the hybridization, culture and law do not go without limits and boundaries, differentiation, codes, and programmes (just and unjust, valid and invalid, licit and illicit, etc). The point, however, is that the practical institutionalization of those limits and lines of the nomos no longer coincides with a particular territorial culture. If the anthropological cronotopology is essential, the cybermetamorphosis of man, which enables him to participate in new levels of reality, widens the space of the possible claiming for new boundaries - anthropologically cultural (product of human autonomy) but also - more and more intrinsically inter and transcultural.

The experience of the other, the imagination of the different, the projection to the not yet (E. Bloch) provide guidance, ensuring law's continuous dynamism and openness, notwithstanding (rather due to) its permanent working of division, distribution, attribution and commission. From a constitutional perspective, this is the work of institutionalizing the conditions for human capability, according to ideas of justice.

\footnotetext{
home: Transculturality trough literature", in Proceedings of CAIR10, the first Conference on Applied Interculturality Research, Graz, Austria, 7-10 2010; Chielozona EZE, "Cosmopolitan Solidarity: Negotiating Transculturality in Contemporary Nigerian Novels", in English in Africa, Vol. 32, No. 1, May, 2005, pp. 99-112.

65 Alasdayr PENNYCOCK, Global Englishes and Transcultural Flows, op. cit.

${ }^{66}$ Franz SCHULZE-ENGLER, "Introduction", in Franz SCHULZE-ENGLER/ Sissy HELFF, Transcultural English Studies: Theories, Fictions, Realities (Volume 12 ASNEL PAPERS), Rodopi, 2009, pp. ix-xvi.;

${ }^{67}$ This is not the place nor the time to develop this point. However, it already goes without saying that such a conspicuous mobilization of culture and law can easily be hijacked and become an instrument of ideological manipulation or acting as an indiscussed strategy of foundationlegitimation of the status quo of globalization, able to inhibit or block radical critical reflection and advocacy towards emancipatory social transformation. No wonder the use of transculturality, translegality and transconstitutionality tropes can be under suspicion; effectively, it should never dispense continuous surveilance.
} 
Not surprisingly, for Canotilho, interconstituionality as interculturality is fostered by inter-organizative texts towards egalitarian and universal cohesion, marked by symbolic belongings like the membership and participation in a community of free, equal and autonomous individuals; W. Welsh speaks about human rights transculturality and Terry Eagleton reminds us that common cultures, namely common social institutions, do not imply cultural uniformity.

If we don't want inter- and transcultural adjectives and adverbs to become mere disguises for law's deference to the hegemonic powers of economy (within a rbetorical strategy aimed at the legitimation of the status quo), our intellectual and practical efforts will have to be shifted to the other side of the moon - imagining, uncovering, and implementing the social, political and juridical solidarities (around social justice claims), produced or propitiated by globalization, therefore exploring their countervailing or counterhegemonic potential of correction and gradual transformation of the real (and its layers of reality).

Perhaps public institutions and new public services, committed to the realization of social rights, can regain their breath with the new winds blowing from the doctrinal reflections on the commons, the theories of global goods or the discourses concerning social services of general interest $t^{8}$.

For the moment, our aspirations run a little lower. Our time was scarce, thus we had to resign ourselves to a few theoretical considerations and some purposive and critical-reconstitutive hints.

However, to those who rapidly demise social justice projects, especially transnational ones, with labels of onirism, one can certainly reply - for it is always timely - recalling what William Butler Yeats wrote, in 1914, under the selfdescription of "an epigraph from an old play.": "In dreams begins responsibility."

And so it is, indeed, even if - as I keep reminding in some of my writings - the only problem with utopias is that our dreams cannot see us (G. Agamben).

\footnotetext{
68 The enthusiasm with more ambitious expressions, like global constitutionalism, is currently mirrored in several works and publications.
} 